\title{
The Memory in the Celebration of Organizational Identity
}

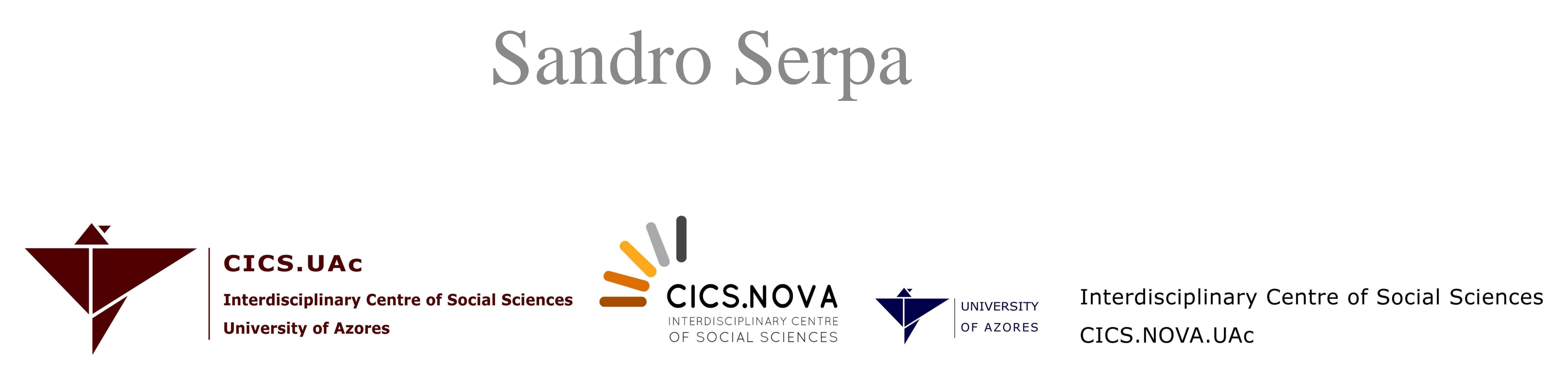

\&: Interdisciplinary Social Sciences 


\section{Background}

Legitimacy is essential for the perpetuation of an organization.

This legitimization process can be achieved through the building of an organizational identity as expression of a collective destiny (Whetten, 2006).

The identity of an organization is never guaranteed, requiring it to be cultivated, especially on the part of its leadership (Perrenoud, 1994; Pettigrew, 1985; Pettigrew, 1987; Pettigrew, Woodman, \& Cameron, 2001; Prados, 2010; Tavares, 2004) through the management of memories (Halbwachs, 1990) selectively shaping what is memorable (Zerubavel, 2003) even in situations of (self)celebration (Mejía, \& Álvarez, 2005; Serpa, 2015, 2016). 


\section{Research question}

What is the relevance ascribed to the mobilization of memory by the leadership in the (self)celebration of organizational identity by the centenary of Asilo de Infância Desvalida da Horta?

\section{Methods:}

- organizational case study (Yin, 2009) of a boarding school for disadvantaged young girls with a lay Board of Directors and managed by Religious Sisters;

- focuses on the celebration of the centenary: from December 25 to 28, 1958;

- inductive qualitative document analysis (formal and informal documents of / on the organization and publications in a local newspaper) (Bardin, 1995). 


\section{Preliminary results:}

a) record for posterity

b) conveyance of a positive external image

c) legitimation of the leadership's action

d) promotion of internal cohesion a) a manuscript with written and photographic records, in which the author, the President of the Asylum's Board of Directors, "condensed the secular history of the Institution in countless details" (O Telégrafo, 1958).

b) delivery of the program of these celebrations to the visitors, which includes photographs that highlight the improvement of the facilities;

- "Symbolizing the 326 children who have lived in the Asylum since its establishment and, by intention of the founders, patrons and brothers of the same Asylum, 326 alms [bread and meat] will be distributed, after dinner" (Asilo de Infância Desvalida da Horta, 1958).

c) parallelism of memory, "similarly to what was done in 1858, when this Asylum was established, the President of the Administrative Board shall be accompanied by six children to be admitted in this day" (Asilo de Infância Desvalida da Horta, 1958).

d) Resolution of the Board of Directors to associate the celebration of the 25 years of presence of the Religious sisters in the Asylum with the celebrations of the centenary, "One of the first Sisters who served in this institution will unveil the portrait of the Rev. Mother General of the Congregation of the Portuguese Hospitaller Franciscan Sisters" (Asilo de Infância Desvalida, 1958). 


\section{Conclusion}

This mobilization of memory by the leadership has several goals:

- leave a record for posterity;

- convey a positive image to the exterior;

- legitimize its action in this organization;

- foster internal cohesion.

This commemoration was a celebration of the success of this organization, embodied in its corporate identity, assuming the memory mobilization by leadership as a key resource in this process of legitimation. 


\section{References}

Asilo de Infância Desvalida da Horta. Festas comemorativas do primeiro centenário da sua fundação [Commemorative celebrations of the first centenary of its establishment]. December 28, 1958 [Programme].

Bardin, L. (1995). Análise de conteúdo [Content analysis]. Lisboa: Edições 70.

Halbwachs, M. (1990). A memória coletiva [The collective memory]. São Paulo: Edições Vértice e Editora Revista dos Tribunais, Ltda.

Lemos, R. R. G. de (1958). Asilo de Infância Desvalida da Horta. 1858-1958..

Mejía, O. M. A., \& Álvarez, M. X. Q. (2005). Memoria colectiva y organizaciones [CManuscript work to celebrate one century of existenceollective memory and organizations]. Univ. Psychol. Bogotá (Colombia), 4(3), 285-296.

O Telégrafo (1958). Ano 66, November 30, 1958, no. 17706, p. 6.

Perrenoud, P. (1994). A organização, a eficácia e a mudança, realidades construídas pelos atores [The organization, effectiveness and change, realities constructed by the actors]. In M. G. Thurler, \& P. Perrenoud (Eds.). A escola e a mudança. Contributos sociológicos [School and change. Sociological contributions] (pp. 133-159). Lisboa: Escolar Editora.

Pettigrew, A. M. (1985). Examining change in the long-term context of culture and politics. In J. M. Pennings et al. (Eds.). Organizational strategy and change (pp. 269-318). S. Francisco: Jossey Bass.

Pettigrew, A. M. (1987). Context and action in the transformation of the firm. Journal of Management Studies, 24(6), 649-70.

Pettigrew, A. M., Woodman, R. W., \& Cameron, K. (2001). Studying organizational change and development: Challenges for future research. Academy of Management Journal, 44(4), 697-712.

Prados, I. de la T. (2010). Identidad institucional de las organizaciones del tercer sector [Institutional identity of the third sector organizations]. Revista Internacional de Organizaciones (RIO), 5, 7-29.

Serpa, S. (2016). A sociological approach to institutional communication: The public image in organizational administration in education. International Education Studies, 9(1), 79-90. doi:10.5539/ies.v9n1p79.

Serpa, S. (2015). Regulação e autonomia na procura de legitimidade na fundação do Asilo de Infância Desvalida da Horta [Regulation and autonomy in the search for legitimacy in the establishment of Asilo de Infância Desvalida da Horta]. In A. P. Almeida, L. L. Dinis, \& G. R. da Silva (Eds.), Actas do IV Congresso Ibero-Americano de Políticas e Administração da Educação - 2014 Políticas e Práticas de Administração e Avaliação na Educação Ibero-Americana [Proceedings of the IV Iberan-American Congress of Educational Policies and Administration - 2014 Administration and Evaluation Policies and Practices in Iberan-American Education]. Lisboa: Fórum Português de Administração Educacional.

Tavares, S. (2004). Vinculação dos indivíduos às organizações [Individuals’ binding to organizations]. In J. M. C. Ferreira, J. Neves, \& A. Caetano (Eds.). (2004), Manual de psicossociologia das organizações [Handbook of psichology of the organizations] (pp. 307-333). Lisboa: McGraw-Hill.

Zerubavel, E. (2003). Time maps: Collective memory and the social shape of the past. Chicago: The University of Chicago Press.

Yin, R. K. (2009). Case study research: Design and methods. (4th ed.). Los Angeles: SAGE Publications.

Whetten, D. A. (2006). Albert and Whetten revisited strengthening the concept of organizational identity. Journal of Management Inquiry, 15(3), 219-234. doi: $10.1177 / 1056492606291200$. 